\title{
Effects of short-term feeding of Bt MON810 maize on growth performance, organ morphology and function in pigs
}

\author{
Maria C. Walsh ${ }^{1}$, Stefan G. Buzoianu ${ }^{1,2}$, Gillian E. Gardiner ${ }^{2}$, Mary C. Rea ${ }^{3}$, R. Paul Ross ${ }^{3,4}$, \\ Joseph P. Cassidy ${ }^{5}$ and Peadar G. Lawlor ${ }^{1 *}$ \\ ${ }^{1}$ Teagasc, Pig Development Department, Animal and Grassland Research and Innovation Centre, Moorepark, Fermoy, \\ County Cork, Republic of Ireland \\ ${ }^{2}$ Department of Chemical and Life Sciences, Waterford Institute of Technology, Waterford, Republic of Ireland \\ ${ }^{3}$ Teagasc, Food Research Centre, Moorepark, Fermoy, County Cork, Republic of Ireland \\ ${ }^{4}$ Alimentary Pharmabiotic Centre, University College Cork, Cork, Republic of Ireland \\ ${ }^{5}$ Veterinary Sciences Centre, University College Dublin, Belfield, Dublin, Republic of Ireland
}

(Received 4 February 2011 - Revised 13 April 2011 - Accepted 28 April 2011 - First published online 1 July 2011)

\section{Abstract}

Male weanling pigs ( $n$ 32) with a mean initial body weight of $7.5 \mathrm{~kg}$ and a mean weaning age of $28 \mathrm{~d}$ were used in a $31 \mathrm{~d}$ study to investigate the effects of feeding GM (Bt MON810) maize on growth performance, intestinal histology and organ weight and function. At weaning, the pigs were fed a non-GM starter diet during a $6 \mathrm{~d}$ acclimatisation period. The pigs were then blocked by weight and litter ancestry and assigned to diets containing 38.9\% GM (Bt MON810) or non-GM isogenic parent line maize for $31 \mathrm{~d}$. Body weight and feed disappearance were recorded on a weekly basis ( $n$ 16/treatment), and the pigs ( $n$ 10/treatment) were killed on day 31 for the collection of organ, tissue and blood samples. GM maize-fed pigs consumed more feed than the control pigs during the $31 \mathrm{~d}$ study $(P<0.05)$ and were less efficient at converting feed to gain during days $14-30(P<0 \cdot 01)$. The kidneys of the pigs fed GM maize tended to be heavier than those of control pigs $(P=0 \cdot 06)$; however, no histopathological changes or alterations in blood biochemistry were evident. Small intestinal morphology was not different between treatments. However, duodenal villi of GM maize-fed pigs tended to have fewer goblet cells $/ \mu \mathrm{m}$ of villus compared with control pigs $(P=0 \cdot 10)$. In conclusion, short-term feeding of Bt MON810 maize to weaned pigs resulted in increased feed consumption, less efficient conversion of feed to gain and a decrease in goblet cells/ $\mu \mathrm{m}$ of duodenal villus. There was also a tendency for an increase in kidney weight, but this was not associated with changes in histopathology or blood biochemistry. The biological significance of these findings is currently being clarified in long-term exposure studies in pigs.

Key words: Maize: Cry1Ab: GM plants: Safety

The inclusion of GM plants in animal feed and for human consumption has increased consistently over the past 15 years since they were first cultivated in $1996^{(1)}$. During this time, the cultivation area of GM crops has increased eightyseven-fold reaching 148 million hectares worldwide in 2010, making the procurement of exclusively non-GM crops more difficult and expensive. GM maize is the second most important biotech crop after GM soyabeans ${ }^{(1)}$ and the first one to have a wider variety of genetic modifications than glyphosate-tolerant soyabean.

Since the introduction of GM crops, much debate, both within and outside the scientific community, has centred on issues related to safety for consumption. The most dominant agronomic traits introduced by genetic engineering include herbicide tolerance, insect resistance $(\mathrm{Bt})$ and stacking of both of these traits ${ }^{(1)}$. These genetically engineered traits offer the possibility of higher agronomic productivity in times of insect infestation without the use of insecticides and/or the use of less expensive broad-spectrum herbicides for weed control $^{(2)}$. However, the increased usage of GM crops for direct human consumption and feeding to meatand milk-producing animals has led to public concern ${ }^{(3)}$. These concerns, however, do not relate to the GM technology itself but to any unintended consequences that may arise from its use. Consumer concerns are mostly related to a perceived risk to health, development of toxicity, allergenicity of the transgenic proteins or the transfer of antibiotic resistance from the plant to bacteria residing in the human gastrointestinal tract ${ }^{(2)}$. Other concerns, such as gene transfer from GM crops to indigenous plants, reducing biodiversity and influence of the GM crops on non-target species ${ }^{(3-6)}$, are associated with environmental issues. 
Bt MON810 maize is engineered to express the truncated Cry1Ab toxin from Bacillus thuringiensis, which confers resistance to the European maize borer. This toxin interacts with the target larvae's intestinal cells disrupting the intestinal lining leading to death ${ }^{(7-9)}$. However, the toxin is believed to be non-toxic to mammals, birds, reptiles and amphibians due to a lack of specific receptors in the intestinal tract ${ }^{(7)}$. The Cry $1 \mathrm{Ab}$ protein has no homology to any allergenic proteins and was successfully degraded in simulated gastric conditions $^{(10)}$. Trials conducted with Bt maize in pigs, cattle and poultry have shown no significant differences in performance or demonstrated any adverse health effects ${ }^{(11-14)}$. However, some studies found subtle histopathological changes in rats $^{(15)}$ and altered immune responses in mice ${ }^{(16)}$ and fish ${ }^{(17)}$ that were fed $\mathrm{Bt}$ maize. Currently, GM organisms receive European Union authorisation for use following pre-market risk assessment, which focuses on the risk that untoward responses will arise from exposure to GM organisms. The main concern with GM organisms is that the unintended responses may not be evident until a genetically diverse population has been exposed to it for a long period of time. Postmarket monitoring of GM organisms may reveal any long-term effects of GM exposure not identified during the short-term pre-market risk assessment ${ }^{(18)}$.

In the present study, we evaluated in pigs the effects of $31 \mathrm{~d}$ of feeding Bt MON810 maize compared with an isogenic parent line maize. Particular attention was afforded to changes in growth performance, intestinal morphology and organ pathology and function in an attempt to identify any changes that may serve as an early warning sign for a biological effect. To our knowledge, this is the first study in pigs that has simultaneously evaluated the safety of Bt MON810 maize over such a wide range of physiological processes.

\section{Materials and methods}

\section{Experimental design and diets}

The pig trial complied with European Union Council Directive 91/630/EEC (outlines minimum standards for the protection of pigs) and European Union Council Directives 98/58/EC (concerns the protection of animals kept for farming purposes) and was approved by, and a licence obtained from, the Irish Department of Health and Children. Ethical approval was obtained from the Teagasc and Waterford Institute of Technology ethics committees. A total of thirty-two crossbred (Large White $\times$ Landrace) weanling pigs (entirely males) were weaned at approximately $28 \mathrm{~d}$ of age and were blocked by weight and litter, and randomly assigned to one of two dietary treatments: (1) non-GM isogenic parent line of maize (Pioneer PR34N43) and (2) GM maize (Pioneer PR34N44 event MON810). Planted seeds derived from MON810 and its parental control maize (PR34N44 and PR34N43 varieties, respectively) were grown simultaneously side by side in Valtierra, Navarra and Spain. A non-GM starter diet was fed ad libitum for the first $6 \mathrm{~d}$ post-weaning during a baseline acclimatisation period and either the non-GM or GM maize experimental diets were fed for the remaining $31 \mathrm{~d}$. The diets were manufactured in the Moorepark feed mill and were formulated to meet or exceed the National Research Council ${ }^{(19)}$ requirements for weanling pigs (Table 1). Stringent quality-control measures were used to avoid cross contamination of non-GM with GM diets. Carry-over in the feed manufacturing system was minimised by flushing the system with non-GM ingredients and the preparation of non-GM diets before diets containing the GM maize. In addition, non-GM soyabean meal was used in the manufacture of all diets. The cereals were ground by a hammer mill through a $3 \mathrm{~mm}$ screen before mixing. The diets were pelleted to $5 \mathrm{~mm}$ diameter after steam conditioning to $50-55^{\circ} \mathrm{C}$. Proximate (FBA Laboratories, Waterford, Ireland) and amino acid analyses (Sciantec Analytical Services Limited, Cawood, UK) were performed on all diets. Representative samples of feed were taken from each treatment before feeding according to Hartnell et al. ${ }^{(20)}$. Before analysis, the samples were ground through a $2 \mathrm{~mm}$ screen in a Christy Norris hammer mill. The DM was determined by oven drying for $4 \mathrm{~h}$

Table 1. Composition of acclimatisation starter diet and experimental diets (as-is basis, \%)

\begin{tabular}{|c|c|c|c|}
\hline & \multirow{2}{*}{$\begin{array}{c}\begin{array}{c}\text { Baseline } \\
(\text { day }-6 \text { to }-1)\end{array} \\
\text { Non-GM }\end{array}$} & \multicolumn{2}{|c|}{$\begin{array}{l}\text { Experimental } \\
\text { (days 0-31) }\end{array}$} \\
\hline & & Non-GM & GM \\
\hline \multicolumn{4}{|l|}{ Ingredient (\%) } \\
\hline Maize (non-GM) & $27 \cdot 33$ & 38.88 & - \\
\hline Maize (GM - MON810) & - & - & 38.88 \\
\hline Soya Hi-Pro (non-GM) & 24.00 & $25 \cdot 00$ & $25 \cdot 00$ \\
\hline Lactofeed $70^{\star}$ & $25 \cdot 00$ & $20 \cdot 00$ & $20 \cdot 00$ \\
\hline Immunopro $35 \dagger$ & 12.50 & 9.00 & 9.00 \\
\hline Fat, soya oil & 8.00 & 4.00 & 4.00 \\
\hline Lysine $\mathrm{HCl}(78.8)$ & 0.30 & 0.30 & 0.30 \\
\hline DL-Met & 0.25 & 0.20 & 0.20 \\
\hline L-Thr (98) & $0 \cdot 12$ & $0 \cdot 12$ & $0 \cdot 12$ \\
\hline L-Try & $0 \cdot 10$ & $0 \cdot 10$ & $0 \cdot 10$ \\
\hline Premix $\ddagger$ & 0.30 & 0.30 & 0.30 \\
\hline Mycosorb§ & 0.20 & 0.20 & 0.20 \\
\hline Salt & 0.30 & 0.30 & 0.30 \\
\hline Dicalcium phosphate & 0.50 & 0.50 & 0.50 \\
\hline Limestone flour & $1 \cdot 10$ & $1 \cdot 10$ & $1 \cdot 10$ \\
\hline \multicolumn{4}{|c|}{ Analysed chemical composition (\%) } \\
\hline DM & 91.3 & 89.4 & $89 \cdot 2$ \\
\hline Crude protein & $20 \cdot 9$ & $20 \cdot 9$ & $21 \cdot 1$ \\
\hline Fat & $9 \cdot 6$ & $6 \cdot 1$ & 5.9 \\
\hline Crude fibre & $1 \cdot 7$ & $2 \cdot 1$ & 1.9 \\
\hline Ash & $6 \cdot 3$ & 5.5 & $5 \cdot 6$ \\
\hline Lysine & $1.55 \|$ & 1.42 & 1.42 \\
\hline Call & 0.83 & 0.78 & 0.78 \\
\hline $\mathrm{P} \|$ & 0.61 & 0.59 & 0.59 \\
\hline$D E(M J$ of $D E / k g) \|$ & $16 \cdot 33$ & $15 \cdot 38$ & $15 \cdot 38$ \\
\hline Pellet durability (g) & -9 & $96 \cdot 35$ & $96 \cdot 73$ \\
\hline Pellet diameter $(\mathrm{mm})$ & - & 5.08 & $5 \cdot 11$ \\
\hline Pellet hardness (kg) & - & $4 \cdot 30$ & 3.70 \\
\hline
\end{tabular}

$\mathrm{DE}$, digestible energy.

* Lactofeed 70 contains $70 \%$ lactose, $11.5 \%$ protein, $0.5 \%$ oil, $7.5 \%$ ash and $0.5 \%$ fibre (Volac, Cambridge, UK).

† Immunopro 35 is a whey protein powder product containing $35 \%$ protein (Volac). $\ddagger$ Premix provided per kg of complete diet: $\mathrm{Cu}, 155 \mathrm{mg}$; Fe, $90 \mathrm{mg}$; Mn, $47 \mathrm{mg} ; \mathrm{Zn}$ $120 \mathrm{mg}$, I, $0.6 \mathrm{mg}$; Se, $0.3 \mathrm{mg}$; vitamin $\mathrm{A}, 6000 \mathrm{IU}$; vitamin $\mathrm{D}_{3}, 1000 \mathrm{IU}$; vitamin $\mathrm{E}$ $100 \mathrm{IU}$; vitamin $\mathrm{K}, 4 \mathrm{mg}$; vitamin $\mathrm{B}_{12}, 15 \mu \mathrm{g}$; riboflavin, $2 \mathrm{mg}$; nicotinic acid, $12 \mathrm{mg}$; pantothenic acid, $10 \mathrm{mg}$; choline chloride, $250 \mathrm{mg}$; vitamin $\mathrm{B}_{1}, 2 \mathrm{mg}$; vitamin $\mathrm{B}_{6}$, $3 \mathrm{mg}$; endox, $60 \mathrm{mg}$.

$\S$ Mycosorb is an organic mycotoxin absorbent (Allech, Inc., Dunboyne, County Meath, Ireland).

$\|$ Calculated values.

ๆ Baseline non-GM maize diet was fed in the form of meal. 
Table 2. Proximate, carbohydrate and amino acid analysis of $\mathrm{Bt}$ MON810 maize and isogenic parent line maize (as-is basis)

\begin{tabular}{lcc}
\hline & Non-GM maize & GM maize \\
\hline$\%$ & & \\
DM & 88.1 & 87.4 \\
Crude protein & $7 \cdot 7$ & 7.4 \\
Fat & 3.8 & 3.3 \\
Crude fibre & $2 \cdot 6$ & $2 \cdot 0$ \\
Ash & 1.2 & 1.6 \\
Starch & 61.9 & $64 \cdot 1$ \\
Sugar (sucrose) & 1.20 & $2 \cdot 16$ \\
ADF & 4.03 & 3.48 \\
NDF & 11.50 & 11.20 \\
ADL & 1.01 & 1.01 \\
Enzyme-resistant starch & 5.93 & 3.58 \\
Water-soluble carbohydrate & $2 \cdot 13$ & 3.16 \\
DE (MJ of DE/kg) & 15.42 & $15 \cdot 29$ \\
NE (MJ of NE/kg) $\dagger$ & 12.12 & $12 \cdot 12$ \\
Lys & 0.32 & 0.31 \\
Met & 0.16 & 0.15 \\
Cys & 0.22 & 0.22 \\
Thr & 0.34 & 0.32 \\
Try & 0.10 & 0.10 \\
\hline
\end{tabular}

ADF, acid-detergent fibre; NDF, neutral-detergent fibre; ADL, acid-detergent lignin; $\mathrm{DE}$, digestible energy; $\mathrm{NE}$, net energy.

*Calculated from equation no. 24 in Noblet \& Perez ${ }^{(46)}$ using analysed values on an as-is basis.

†Calculated from equation no. 11 in Noblet et al..$^{(47)}$ using analysed values on an as-is basis.

at $103^{\circ} \mathrm{C}$. Ash was obtained by incineration in a muffle furnace (Gallenkamp, London, UK) at $550^{\circ} \mathrm{C}$ overnight. Crude protein was determined as $\mathrm{N} \times 6.25$ using a LECO FP - 2000 analyser (Leco Instruments Limited, Stockport, Cheshire, UK). Fat was determined by extraction with perchlorethylene in a Foss Let 15300 (A/S N. Foss Electric, Hillerod, Denmark) according to the method described by Usher et al. ${ }^{(21)}$. Crude fibre was measured by a Fibertec semi-automatic system (Tecator, Hoganas, Sweden). Analysis of the carbohydrate fractions, amino acid profile (Sciantec Analytical Services Limited) and proximate composition (FBA Laboratories) of the GM and non-GM maize was also performed (Table 2 ). The carbohydrate fractions that were quantified included starch, sugar as sucrose, acid-detergent fibre, neutral-detergent fibre, water-soluble carbohydrate, enzyme-resistant starch and acid-detergent lignin. The quality of the manufactured pellets was also assessed, including pellet durability, diameter and hardness, as described previously by MacMahon \& Payne ${ }^{(22)}$ (Table 1). The GM and non-GM maize was tested for the presence of the cry $1 A b$ gene by MON810 event-specific PCR (IdentiGen, Dublin, Ireland). The GM and non-GM maize was analysed for aflatoxin (B1, B2, G1, G2), ochratoxin, zearalenone, vomitoxin, T2 toxin and fumonisin by ELISA (Oldcastle Laboratories Limited, Meath, Ireland). Both types of maize were also analysed for pesticide residues by testing against a panel of 355 different active substances (Pesticide Control Service, Department of Agriculture, Backweston, Kildare, Ireland).

\section{Animal housing and management}

The pigs were housed individually in a total of four rooms with eight pigs per room (16 pigs/treatment). Each treatment group was represented in each room to avoid additional variations due to environment. The pigs were individually penned in fully slatted pens $(1.07 \mathrm{~m} \times 0.6 \mathrm{~m})$ with plastic slats (Faroex, Manitoba, Canada). The pigs had unlimited access to water and feed through a single bowl drinker fitted in each pen and a door-mounted stainless-steel feed trough ( $410 \mathrm{~mm}$ long) with a centre divider, respectively. Heat was provided by a wallmounted electric bar heater (Irish Dairy Services, Portlaoise, Ireland) and thermostatically controlled. The rooms were naturally ventilated with an air inlet in the door and exhaust by way of a roof-mounted chimney. Temperature was maintained at $28-30^{\circ} \mathrm{C}$ in the first week and reduced by $2^{\circ} \mathrm{C}$ per week to $22^{\circ} \mathrm{C}$ in the fourth week. The pigs were observed closely at least three times daily. Any pigs showing signs of ill health were treated as appropriate. All veterinary treatments were recorded including identity of pig, symptom, medication used and dosage. Individual body weight and feed disappearance were recorded on days $-6,0,7,14,21,28$ and 31 of the study.

\section{Intestinal, organ and blood sampling}

On day 31, ten pigs/treatment were killed by captive bolt stunning followed by exsanguination. The last meal was administered $3 \mathrm{~h}$ before killing. The heart, liver, spleen, kidneys and a sample of semi-tendinosus muscle were removed first, to prevent contamination with digesta, followed by the entire gastrointestinal tract. Samples were also taken from the duodenum ( $15 \mathrm{~cm}$ caudal from the pyloric junction), jejunum (midway between the pyloric junction and ileo-caecal junction) and ileum ( $15 \mathrm{~cm}$ cranial from the ileo-caecal junction) for histological analysis (as outlined below). Blood samples were taken from the anterior vena cava of ten pigs per treatment at slaughter (day 31) for plasma collection. Plasma was stored at $-20^{\circ} \mathrm{C}$ for subsequent blood biochemical analysis. The heart, liver, kidneys and spleen were removed, trimmed of any superficial fat or blood clots and weighed. Samples were then taken from the liver (distal end centre of central lobe), kidney (cortex and medulla), spleen (anterior end of spleen), heart (left ventricle wall) and semi-tendinosus muscle for histological examination.

\section{Intestinal and organ histology}

Small intestinal (duodenal, jejunal and ileal) and organ (heart, liver, kidney, spleen and muscle) samples were rinsed in PBS and placed in a No-Tox fixative (Scientific Device Lab, Des Plaines, IL, USA) on a shaker for a minimum of $48 \mathrm{~h}$. The samples were then dehydrated through a graded alcohol series, cleared with a Sub-X clearing agent (Surgipath, Richmond, IL, USA) and embedded in paraffin. Tissue samples were sliced using a microtome (Leica RM2235, Wetzlar, Germany), mounted on a microscope slide and stained with haematoxylin and eosin (Sigma-Aldrich, St Louis, MO, USA) for light microscopic examination. Determination of the gross morphological parameters of the intestinal structure (villus height and crypt depth) was conducted according to Applegate et $a l^{(23)}$ and Gao et $a l^{(24)}$. For each pig, ten villi and crypts were measured on three to four fields of view, 
Table 3. List of histological indicators used for the identification of cell and organ dysfunction in the liver, heart, spleen, kidneys and muscle of weanling pigs fed GM or non-GM maize for $31 \mathrm{~d}$

Indicators of organ dysfunction

Cell swelling

Cytoplasmic vacuolar development

Cytoplasmic vacuolar development due to fatty accumulation (fatty change) Cytoplasmic/nuclear shrinkage/fragmentation

Cell apoptosis/degeneration/necrosis

Haemorrhage/oedema/inflammation/fibrosis

Tissue hyperplasia/metaplasia

Cell pigmentation

Alteration to blood vessel structure/integrity

and the means were utilised for statistical analysis. The goblet cell number was determined by periodic acid-Schiff staining according to Thompson \& Applegate ${ }^{(25)}$. Positively stained periodic acid-Schiff cells were enumerated on ten villi/ sample, and the means were utilised for statistical analysis. Organ samples were examined for any histological indicators of organ dysfunction by an experienced histopathologist and characterised based on the indicators of cell and organ dysfunction listed in Table 3.

\section{Blood biochemistry}

Liver and kidney function was assessed by measuring the concentrations of aspartate aminotransferase, alanine aminotransferase, $\gamma$-glutamyltransferase, creatinine, urea and total protein in plasma taken at slaughter (day 31). Plasma samples were prepared using appropriate kits according to the manufacturer's instructions and analysed using an Alfa Wassermann ACE Clinical Chemistry system (Alfa Wassermann BV, Woerden, The Netherlands).

\section{Statistical analysis}

All data were analysed as a complete randomised block design using the GLM procedures of SAS (SAS Institute, Inc., Cary, NC, USA) ${ }^{(26)}$. For all response criteria, the individual pig was the experimental unit. Treatment effect was tested against the residual error term with initial body weight as a blocking factor. Growth performance, gastrointestinal histology and blood biochemistry data were analysed as a one-factor ANOVA using the GLM procedure of SAS. Organ weights were also analysed as a one-factor ANOVA using the GLM procedure of SAS using the final body weight (day 31) as a covariate in the model. The level of significance for all tests was $P<0 \cdot 05$. Trends were reported up to $P=0 \cdot 10$.

\section{Results}

Analysis of GM and non-GM maize for the cry1Ab gene, mycotoxins, pesticide residues and carbohydrate fraction

GM maize was found to have a $>5 \%$ event-specific $c r y 1 A b$ gene insert. However, the non-GM maize was also found to have event-specific cry $1 \mathrm{Ab}$ gene insert but only of $0.20 \%$. Non-GM maize was also positive for the cp4epsp gene from
Round-up Ready Soybean; however, this transgene could not be quantified due to the absence of a reference sample. The levels of all mycotoxins detected in the GM and nonGM maize were below the maximum allowable levels as outlined in the European Union legislation (Commission Regulation (EC) no. 1881/2006). GM and non-GM maize were also negative for all the pesticide residues tested. GM maize was found to have $2 \cdot 2 \%$ greater starch content, $1.03 \%$ greater water-soluble carbohydrate content, $0.55 \%$ greater acid detergent fibre, $1 \%$ greater sucrose content and $2.35 \%$ lesser enzyme-resistant starch than non-GM maize (Table 2). Neutral detergent fibre, acid detergent lignin and digestible energy content were similar in each of the two maize types. Non-GM and GM maize were also similar in chemical composition and amino acid concentration (Table 2).

\section{Effect of feeding diets containing GM or non-GM maize} on health, body weight and growth performance

At 2 weeks after the beginning of the study, two pigs (one from each treatment) were observed to have nasal discharge, difficulties in breathing and a lack of appetite. The pigs were administered with injectable Enrofloxacin $(2.5 \mathrm{mg} / \mathrm{kg}$ body weight) for $3 \mathrm{~d}$. By the end of the treatment period, both pigs no longer displayed symptoms of ill health. No other pigs displayed signs of ill health throughout the trial.

There were no differences in feed consumption, average daily gain and feed conversion efficiency between the treatment groups during the first $14 \mathrm{~d}$. During days 14-30, the pigs fed the GM maize diet consumed more feed (Table 4 ; $P=0.02)$ and had poorer feed conversion efficiency than pigs fed the non-GM maize diet $(P=0 \cdot 007)$. Overall, the pigs fed the GM maize diet had higher daily feed consumption $(P=0.03)$ and had numerically greater average daily gain and heavier body weight on day 30 compared with pigs fed the non-GM maize diet, but this was not statistically significant.

Table 4. Effects of feeding GM or non-GM maize for $30 \mathrm{~d}$ on weanling pig growth performance

(Mean values with their standard errors, $n$ 16)

\begin{tabular}{lcccc}
\hline & Non-GM maize & GM maize & SE & $P$ \\
\hline ADG $(\mathrm{g} / \mathrm{d})$ & & & & \\
$0-14 \mathrm{~d}$ & 391 & 427 & 19.1 & $\mathrm{NS}$ \\
$14-30 \mathrm{~d}$ & 738 & 790 & 23.1 & $\mathrm{NS}$ \\
$0-30 \mathrm{~d}$ & 576 & 620 & 18.2 & $\mathrm{NS}$ \\
ADFI $(\mathrm{g} / \mathrm{d})$ & & & & \\
$0-14 \mathrm{~d}$ & 475 & 484 & 19.0 & $\mathrm{NS}$ \\
$14-30 \mathrm{~d}$ & 893 & 1021 & 30.1 & $*$ \\
$0-30 \mathrm{~d}$ & 697 & 770 & 22.9 & $*$ \\
Feed:gain ratio & & & & \\
$0-14 \mathrm{~d}$ & 1.21 & 1.13 & 0.032 & $\mathrm{NS}$ \\
$14-30 \mathrm{~d}$ & 1.21 & 1.29 & 0.016 & $*$ \\
$0-30 \mathrm{~d}$ & 1.22 & 1.24 & 0.015 & $\mathrm{NS}$ \\
Body weight (kg) & & & & \\
$30 \mathrm{~d}$ & 24.7 & 26.0 & 0.56 & $\mathrm{NS}$ \\
\hline
\end{tabular}

$A D G$, average daily gain; ADFI, average daily feed intake.

Mean values were significantly different between two treatments: ${ }^{\star} P<0.05,{ }^{* \star} P<0.01$. 
Table 5. Effects of feeding GM maize or non-GM maize for $31 \mathrm{~d}$ on organ weights and organosomatic indices of weanling pigs

(Mean values with their standard errors, $n 10$ )

\begin{tabular}{|c|c|c|c|c|}
\hline & Non-GM maize & GM maize & SE & $P$ \\
\hline \multicolumn{5}{|c|}{ Organ weights $(g) \dagger$} \\
\hline Kidneys & $145 \cdot 2$ & $161 \cdot 0$ & 4.52 & * \\
\hline Spleen & 47.5 & $54 \cdot 3$ & $2 \cdot 71$ & NS \\
\hline Liver & $690 \cdot 0$ & $665 \cdot 3$ & 17.98 & NS \\
\hline Heart & $133 \cdot 3$ & $142 \cdot 2$ & 3.96 & NS \\
\hline \multicolumn{5}{|c|}{ Organosomatic indicesł } \\
\hline Kidneys & 0.0058 & 0.0061 & 0.00017 & NS \\
\hline Spleen & 0.0019 & 0.0021 & 0.00009 & NS \\
\hline Liver & 0.0270 & 0.0258 & 0.00065 & NS \\
\hline Heart & 0.0052 & 0.0055 & 0.00014 & NS \\
\hline
\end{tabular}

* Mean values were significantly different between two treatments $(P<0 \cdot 10)$.

† Organ weights were calculated using final body weight on day 30 as a covariate.

$\ddagger$ Organosomatic indices were calculated by expressing the organ weights as a fraction of the body weight on day 30 .

\section{Effect of short-term feeding of GM and non-GM maize diets on organ weights}

The weights of the heart, liver and spleen did not differ between treatments. However, the pigs fed GM maize diets tended to have heavier kidneys than control pigs $(161 \cdot 0 \mathrm{v}$. $145.2 \mathrm{~g}$, respectively; $P=0.055$; Table 5 ). There were no differences in organ weights between treatment groups when expressed as organosomatic indices (Table 5).

\section{Effect of feeding GM and non-GM maize diets on small intestinal and organ histology}

Short-term feeding of GM maize to weanling pigs had no effect on duodenal, jejunal or ileal villus height, crypt depth or villus height:crypt depth ratio (Table 6). The number of

Table 6. Effects of feeding GM maize or non-GM maize for $31 \mathrm{~d}$ on small intestinal histology of weanling pigst

(Mean values with their standard errors, $n 10$ )

\begin{tabular}{|c|c|c|c|c|}
\hline & Non-GM maize & GM maize & SE & $P$ \\
\hline \multicolumn{5}{|c|}{ Villus height $(\mu \mathrm{m})$} \\
\hline Duodenum & 787 & 774 & $85 \cdot 0$ & NS \\
\hline Jejunum & 524 & 612 & $54 \cdot 6$ & NS \\
\hline Ileum & 517 & 567 & $20 \cdot 1$ & NS \\
\hline \multicolumn{5}{|c|}{ Crypt depth $(\mu \mathrm{m})$} \\
\hline Duodenum & 517 & 543 & $45 \cdot 3$ & NS \\
\hline Jejunum & 456 & 483 & $18 \cdot 8$ & NS \\
\hline lleum & 378 & 381 & $32 \cdot 3$ & NS \\
\hline \multicolumn{5}{|c|}{ Villus height:crypt depth ratio } \\
\hline Duodenum & 1.60 & 1.43 & 0.238 & NS \\
\hline Jejunum & $1 \cdot 20$ & 1.31 & 0.158 & NS \\
\hline Ileum & 1.43 & 1.57 & 0.112 & NS \\
\hline \multicolumn{5}{|c|}{ Number of goblet cells/villus } \\
\hline Duodenum & 16.5 & $13 \cdot 4$ & $2 \cdot 11$ & NS \\
\hline Jejunum & $8 \cdot 2$ & $9 \cdot 0$ & 1.06 & NS \\
\hline Ileum & $8 \cdot 7$ & $10 \cdot 5$ & 1.96 & NS \\
\hline \multicolumn{5}{|c|}{ Number of goblet cells $/ \mu \mathrm{m}$ of villus } \\
\hline Duodenum & 0.027 & $0.019^{3}$ & 0.0026 & * \\
\hline Jejunum & 0.018 & 0.016 & 0.0021 & NS \\
\hline lleum & 0.017 & 0.018 & 0.0030 & NS \\
\hline
\end{tabular}

* Mean values were significantly different between two treatments $(P<0 \cdot 10)$.

†Ten villi and crypts were measured for each pig and the means were utilised for statistical analysis. goblet cells per villus in the duodenum, jejunum and ileum of the weaned pigs did not differ between treatment groups following a $31 \mathrm{~d}$ feeding period. However, there was a tendency $(P=0 \cdot 10)$ for an increase in the number of goblet cells per $\mu \mathrm{m}$ of duodenal villus in control pigs compared with pigs fed GM maize (Table 6). There were no histopathological indicators of organ dysfunction identified in the samples examined (heart, liver, kidney, spleen and muscle).

\section{Effect of feeding GM and non-GM maize diets on liver and kidney function}

Short-term feeding of GM maize had no effect on plasma total protein or creatinine and urea concentrations, the latter being indicators of kidney function (Table 7). Similarly, there was no effect of treatment on plasma concentrations of the liver enzymes, alanine aminotransferase, aspartate aminotransferase and $\gamma$-glutamyl transferase. In addition, all parameters were within the normal range of values for pigs of this age (Table 7)

\section{Discussion}

To date, research documenting the effect of feeding $\mathrm{Bt}$ MON810 maize to pigs has focused primarily on changes in growth response. To our knowledge, this is the first study in pigs that assesses the effects of feeding Bt MON810 maize on kidney and liver function, intestinal histology and growth performance. Changes in physiological processes in response to GM maize exposure have previously been investigated in other species such as rats, mice, poultry and fish. However, research in this area in pigs has been somewhat limited.

No consistent effects on feed intake and average daily gain have been reported in the numerous pig-feeding trials that have compared GM maize with conventional maize varieties $^{(27-29)}$. However, Custodio et al. ${ }^{(12)}$ reported an increase in average daily feed intake in grow-finish $(17-120 \mathrm{~kg})$ pigs fed transgenic Bt11 maize but not in pigs fed Bt11 maize from 60 to $120 \mathrm{~kg}$. In a similar study with MON810 maize, pigs fed GM maize were reported to have increased average daily gain ${ }^{(30)}$. This was, however, attributed to lower concentrations of the mycotoxin, fumonisin B in the GM maize. Similarly, higher weight in zebrafish fed MON810 maize compared with fish fed an isogenic parent-line maize was attributed to a lower level of mycotoxin in the Bt MON810 maize ${ }^{(31)}$. In the present study, while there was a significant increase in feed intake following Bt MON810 maize consumption, growth rates and body weight of these pigs were only numerically higher than control pigs, suggesting a minimal effect of GM maize on growth parameters measured. Also, the levels of mycotoxin detected in both the GM and non-GM maize were below maximum allowable levels as outlined by European Union legislation (Commission Regulation (EC) no. 1881/2006) and as such cannot explain the difference in feed intake observed between treatments. Analysis of the carbohydrate fractions of GM and non-GM maize highlighted some differences between the two types of maize. Willis et $a l{ }^{(32)}$ found that not all types of fibre influence satiety 
Table 7. Effects of feeding GM maize or non-GM maize for $31 \mathrm{~d}$ on serum concentrations of enzymes and other parameters to assess the liver and kidney function of weanling pigs

(Mean values with their standard errors, $n 10$ )

\begin{tabular}{|c|c|c|c|c|c|c|}
\hline & $\begin{array}{l}\text { Non-GM } \\
\text { maize }\end{array}$ & GM maize & SE & $P$ & $\begin{array}{c}\text { Normal range } \\
\text { for pigs }\end{array}$ & References \\
\hline Total protein $(\mathrm{g} / \mathrm{l})$ & $55 \cdot 1$ & 57.9 & 1.08 & NS & $60-80$ & Baum et al. ${ }^{(48)}$ \\
\hline Creatinine $(\mu \mathrm{mol} / \mathrm{l})$ & 109.5 & 103.0 & 3.74 & NS & $90-240$ & Kaneko ${ }^{(49)}$ \\
\hline Urea $(\mathrm{mmol} / \mathrm{l})$ & 5.9 & $5 \cdot 3$ & 0.51 & NS & $2 \cdot 6-8.0$ & Kaneko ${ }^{(49)}$ \\
\hline \multicolumn{7}{|l|}{ Liver enzymes (U/I) } \\
\hline Alanine aminotransferase & $41 \cdot 1$ & $44 \cdot 8$ & 3.57 & NS & $31-58$ & Stonard ${ }^{(50)}$ \\
\hline Aspartate aminotransferase & $54 \cdot 7$ & $56 \cdot 3$ & 2.96 & NS & $32-84$ & Stonard ${ }^{(50)}$ \\
\hline Gamma glutamyl transferase & 43.6 & 38.1 & 7.63 & NS & $10-60$ & Kaneko ${ }^{(49)}$ \\
\hline
\end{tabular}

equally, and that resistant starch had the greatest impact on satiety. GM maize fed to pigs in the present study had lower levels of resistant starch than non-GM maize. This may account for the higher feed intake observed in GM maizefed pigs compared with pigs fed non-GM maize. However, an effect of feeding GM maize on pig growth may not become evident until the pig has been exposed for a longer period of time. With this in mind, we are currently conducting a longer-term pig-feeding study examining the effect of feeding GM maize to pigs from $12 \mathrm{~d}$ post-weaning to slaughter $(110 \mathrm{~d})$.

In the present $31 \mathrm{~d}$ study, we reported no effect of maize type on the absolute weights of the heart, liver and spleen but found a slight increase in the kidney weights of pigs fed the Bt MON810 maize, indicating possible renal toxicity. However, there was no evidence of any histopathological changes in the kidney or other organs examined. Furthermore, kidney and liver function were unaffected, as evidenced by blood biochemistry data. Similarly, no changes in organ weights were found in rats fed GM rice expressing the Cry1Ab protein for $90 \mathrm{~d}^{(33)}$ or in rats fed MON810 maize at inclusion rates of 11 or $33 \%^{(34)}$. While some research has raised questions as to whether GM maize is responsible for signs of hepatorenal toxicity ${ }^{(35)}$, a three-generation study with rats using modified $\mathrm{Bt}$ maize reported no significant differences in relative organ weights and only minimal histopathological changes in the liver and kidneys, which were independent of diet ${ }^{(15)}$. The increase in kidney weight observed in GM maize-fed pigs in the present study may have arisen as a result of an adaptive phenomenon known as hyperfiltration, which can increase kidney weight in response to elevated serum urea ${ }^{(36)}$. Fermentable carbohydrates in the diet have been shown to enhance microbial fermentation in the caecum and the colon, thus increasing the demand for urea. This increased demand for urea has been shown to be satisfied through urea diffusion from the blood into the caecum and the colon, which in turn lowers the urea load to be filtered by the kidneys ${ }^{(37,38)}$. The GM maize used in the present study was found to be lower in enzyme-resistant starch than the non-GM variety. Therefore, we hypothesise that there was less hindgut microbial fermentation in the GM maize-fed pigs and less urea therefore diffused from the blood into the hindgut. As a result, more serum urea was excreted by the kidneys, which resulted in hypertrophy. While there were no differences in serum urea concentrations between treatments in the present study, subsequent work by our group has reported an increase in serum urea concentration in GM maize-fed pigs after $30 \mathrm{~d}$ of exposure (SG Buzoianu, unpublished results).

The present study demonstrated a lack of effect of $\mathrm{Bt}$ MON810 maize on the small intestinal histology of weanling pigs. Similar findings were reported in studies with Atlantic salmon ${ }^{(39)}$, where, although changes were observed in the intestines of Atlantic salmon parr, they could not be ascribed to dietary inclusion of GM plant material. There was, however, a slight decrease in the number of goblet cells per micrometre of duodenal villus of GM maize-fed pigs in the present study compared with control pigs. Ganessunker et al. ${ }^{(40)}$ previously observed an increase in the number of goblet cells in the small intestine of pigs as a result of total parenteral nutrition, which was correlated with a change in gut microbiota, enhanced inflammation and decreased integrity of the mucosal barrier. The present results show that feeding GM maize does not compromise the small intestinal mucosal barrier, but the alterations in goblet cell number observed in the duodenum may be attributed to changes in gut microbial populations observed in these pigs. Preliminary data from an investigation of the gut microbiota of the GM maize-fed pigs would suggest differences in the relative abundance of certain intestinal microbial populations relative to the control group (SG Buzoianu, unpublished results). Changes in intestinal microbiota have been linked with alterations in the number of goblet cells in other studies ${ }^{(41)}$, and intestinal commensal microbiota have been reported to impact directly on intestinal epithelial functions including those of goblet cells ${ }^{(42)}$ by producing mucin-degrading enzymes ${ }^{(43)}$ or by stimulation of mucin gene expression ${ }^{(44)}$.

In conclusion, the results obtained from the short-term feeding of Bt MON810 maize to weanling pigs have demonstrated no adverse effects on growth performance or intestinal morphology. There were no changes in organ weights, with the exception of a tendency for an increase in kidney weight; however, this was not associated with histopathological or blood biochemical changes. Therefore, based on the parameters investigated in the present study, we can conclude that short-term feeding of Bt MON810 maize to pigs is safe. However, long-term studies are required to fully evaluate safety. Furthermore, since the pig is considered to be an 
excellent model for man due to similarities in gastrointestinal anatomy and physiology ${ }^{(45)}$, similar responses to Bt MON810 maize consumption could be expected in humans. Therefore, the present findings offer at least some assurance to consumers as to the safety of short-term exposure to GM food and feed ingredients and give a greater insight into expected responses in pigs to short-term Bt MON810 maize exposure. However, to comprehensively evaluate the effects of feeding Bt MON810 maize to pigs, long-term feeding studies are necessary and are currently ongoing.

\section{Acknowledgements}

The research leading to these results has received funding from the European Union's Seventh Framework Programme (FP7/2007-2013) under grant agreement no. 211820 and the Teagasc Walsh Fellowship programme and independently of any commercial input, financial or otherwise. None of the authors had a financial or personal conflict of interest in regard to the present study. P. G. L., G. E. G., M. C. R. and R. P. R. secured the funding for the research. P. G. L and G. E. G designed the study. M. C. W., S. G. B., P. G. L. and G. E. G. conducted the study. M. C. W., S. G. B., G. E. G. and M. C. R. conducted the laboratory analysis. J. P. C. performed the histopathological examination of the organs. M. C. W., S. G. B., P. G. L., G. E. G. and M. C. R. wrote the manuscript. All authors read and approved the final manuscript.

\section{References}

1. James C (2010) Global Status of Commericalized Biotech/GM crops: 2010. ISAAA Brief No. 42. Ithaca, NY: ISAAA.

2. Bertoni G \& Marsan PA (2005) Safety risks for animals fed genetic modified (GM) plants. Vet Res Commun 29, Suppl. 2, 13-18.

3. Paparini A \& Romano-Spica V (2004) Public health issues related with the consumption of food obtained from genetically modified organisms. Biotechnol Annu Rev 10, 85-122.

4. Moses V (1999) Biotechnology products and European consumers. Biotechnol Adv 17, 647-678.

5. Malarkey T (2003) Human health concerns with GM crops. Mutat Res 544, 217-221.

6. Hug K (2008) Genetically modified organisms: do the benefits outweigh the risks? Medicina (Kaunas) 44, 87-99.

7. Schnepf E, Crickmore N, Van Rie J, et al. (1998) Bacillus thuringiensis and its pesticidal crystal proteins. Microbiol Mol Biol Rev 62, 775-806.

8. Crickmore N (2005) Using worms to better understand how Bacillus thuringiensis kills insects. Trends Microbiol 13, 347-350.

9. Broderick NA, Robinson CJ, McMahon MD, et al. (2009) Contributions of gut bacteria to Bacillus thuringiensis-induced mortality vary across a range of Lepidoptera. BMC Biol 7, 11.

10. EFSA (2008) Safety and nutritional assessment of GM plants and derived food and feed: the role of animal feeding trials. Food Chem Toxicol 46, S2-S70.

11. Reuter T, Aulrich K \& Berk A (2002) Investigations on genetically modified maize (Bt-maize) in pig nutrition: fattening performance and slaughtering results. Arch Tierernahr 56, $319-326$
12. Custodio MG, Powers WJ, Huff-Longergan E, et al. (2006) Growth, pork quality, and excretion characteristics of pigs fed Bt corn or non-transgenic corn. Can J Anim Sci 86, $461-469$.

13. Shimada N, Murata H, Mikami O, et al. (2006) Effects of feeding calves genetically modified corn Bt11: a clinicobiochemical study. J Vet Med Sci 68, 1113-1115.

14. Flachowsky G, Aulrich K, Bohme H, et al. (2007) Studies on feeds from genetically modified plants (GMP) - contributions to nutritional and safety assessment. Anim Feed Sci Technol 133, 2-30.

15. Kilic A \& Akay MT (2008) A three generation study with genetically modified Bt corn in rats: biochemical and histopathological investigation. Food Chem Toxicol 46, 1164-1170.

16. Finamore A, Roselli M, Britti S, et al. (2008) Intestinal and peripheral immune response to MON810 maize ingestion in weaning and old mice. I Agric Food Chem 56, 11533-11539.

17. Sagstad A, Sanden M, Haugland $\varnothing$, et al. (2007) Evaluation of stress- and immune-response biomarkers in Atlantic salmon, Salmo salar L., fed different levels of genetically modified maize (Bt maize), compared with its near-isogenic parental line and a commercial suprex maize. J Fish Dis 30, 201-212.

18. EFSA (2009) Scientific opinion of tha panel on genetically modified organisms on applications (EFSA-GMO-RXMON810) for the renewal of authorisation for the continued marketing of (1) existing food and food ingredients produced from genetically modified insect resistant maize MON810; (2) feed consisting of and/or containing maize MON810, including the use of seed for cultivation; and of (3) food and feed additives, and feed materials produced from maize MON810, all under regulation (EC) no. 1829/ 2003 from Monsanto. EFSA J 1149.

19. NRC (1998) Nutrient Requirements of Swine, 10th ed. Washington, DC: National Academy Press.

20. Hartnell G, Cromwell G, Dana G, et al. (2007) Best Practices for the Conduct of Animal Studies to Evaluate Crops Genetically Modified for Output Traits [IIFB Committee, editor]. Washington, DC: International Life Science Institute.

21. Usher CD, Green CJ \& Smith A (1973) The rapid estimation of fat in various foods using the Foss-Let density apparatus. Inter J Food Sci Technol 8, 429-437.

22. McMahon MJ \& Payne JD (1991) The Pelleting Handbook. A Guide for Production Staff in the Compound Feed Industry. Sarpsborg: Borregaard Lignotech.

23. Applegate TJ \& Lilburn MS (1999) Effect of turkey (Meleagridis gallopavo) breeder hen age and egg size on poult development. 1. Intestinal growth and glucose tolerance of the turkey poult. Comp Biochem Physiol B Biochem Mol Biol 124, 371-380.

24. Gao C, Zhao J \& Gregersen H (2000) Histomorphometry and strain distribution in pig duodenum with reference to zero-stress state. Dig Dis Sci 45, 1500-1508.

25. Thompson KL \& Applegate TJ (2006) Feed withdrawal alters small-intestinal morphology and mucus of broilers. Poult Sci 85, $1535-1540$

26. SAS (2000) SAS User's Guide. Cary, NC: Statistics SAS Institute, Inc.

27. Bressener G, Hyun Y, Stanisiewski EP, et al. (2002) A comparison of swine performance when fed diets containing Roundup Ready corn (event NK603) control or conventional corn lines. J Anim Sci 80, Suppl. 2, 128.

28. Fischer R, Lewis AJ, Miller PS, et al. (2002) Comparison of swine performance when fed diets containing Roundup 
ready corn (event NK603), control, or conventional corn grown during 2000 in Nebraska. J Anim Sci 80, Suppl. 1, 894.

29. Hyun Y, Bressner GE, Ellis M, et al. (2004) Performance of growing-finishing pigs fed diets containing Roundup Ready corn (event NK603), a nontransgenic genetically similar corn, or conventional corn lines. J Anim Sci 82, 571-580.

30. Piva G, Morlacchini M, Pietri A, et al. (2001) Performance of weaned piglets fed insect protected (MON810) or near isogenic corn. J Anim Sci 79, Suppl. 1, J Dairy Sci 84, Suppl. 1; Poult Sci 80, Suppl. 1; 54th Annual Reciprocal Meat Conference 2, 106.

31. Sissener NH, Johannessen LE, Hevrøy EM, et al. (2010) Zebrafish (Danio rerio) as a model for investigating the safety of GM feed ingredients (soya and maize); performance, stress response and uptake of dietary DNA sequences. Br J Nutr 103, 3-15.

32. Willis HJ, Eldridge AL, Beiseigel J, et al. (2009) Greater satiety response with resistant starch and corn bran in human subjects. Nutr Res 29, 100-105.

33. Schroder M, Poulsen M, Wilcks A, et al. (2007) A 90-day safety study of genetically modified rice expressing Cry1Ab protein (Bacillus thuringiensis toxin) in Wistar rats. Food Chem Toxicol 45, 339-349.

34. Hammond BG, Dudek R, Lemen JK, et al. (2006) Results of a 90-day safety assurance study with rats fed grain from corn borer-protected corn. Food Chem Toxicol 44, 1092-1099.

35. Seralini GE, Cellier D \& de Vendomois JS (2007) New analysis of a rat feeding study with a genetically modified maize reveals signs of hepatorenal toxicity. Arch Environ Contam Toxicol 52, 596-602.

36. Martin W, Armstrong L \& Rodriguez NR (2005) Dietary protein intake and renal function. Nutr Metab 2, 25.

37. Younes H, Demigné C, Behr S, et al. (1995) Resistant starch exerts a lowering effect on plasma urea by enhancing urea $\mathrm{N}$ transfer into the large intestine. Nutr Res 15, 1199-1210.

38. Younes H, Garleb K, Behr S, et al. (1995) Fermentable fibers or oligosaccharides reduce urinary nitrogen excretion by increasing urea disposal in the rat cecum. J Nutr $\mathbf{1 2 5}$, 1010-1016.

39. Sanden M, Berntssen MH, Krogdahl A, et al. (2005) An examination of the intestinal tract of Atlantic salmon,
Salmo salar L., parr fed different varieties of soy and maize. J Fish Dis 28, 317-330.

40. Ganessunker D, Gaskins HR, Zuckermann FA, et al. (1999) Total parenteral nutrition alters molecular and cellular indices of intestinal inflammation in neonatal piglets. JPEN J Parenter Enteral Nutr 23, 337-344.

41. Mair C, Plitzner C, Pfaffl MW, et al. (2010) Inulin and probiotics in newly weaned piglets: effects on intestinal morphology, mRNA expression levels of inflammatory marker genes and haematology. Arch Anim Nutr 64, 304-321.

42. Kim YS \& Ho SB (2010) Intestinal goblet cells and mucins in health and disease: recent insights and progress. Curr Gastroenterol Rep 12, 319-330.

43. Macfarlane S, Woodmansey EJ \& Macfarlane GT (2005) Colonization of mucin by human intestinal bacteria and establishment of biofilm communities in a two-stage continuous culture system. Appl Environ Microbiol 71, 7483-7492.

44. Dohrman A, Miyata S, Gallup M, et al. (1998) Mucin gene (MUC 2 and MUC 5AC) upregulation by gram-positive and gram-negative bacteria. Biochim Biophys Acta 1406, 251-259.

45. Moughan PJ, Birtles MJ, Cranwell PD, et al. (1992) The piglet as a model animal for studying aspects of digestion and absorption in milk-fed human infants. World Rev Nutr Diet 67, 40-113.

46. Noblet J \& Perez JM (1993) Prediction of digestibility of nutrients and energy values of pig diets from chemical analysis. J Anim Sci 71, 3389-3398.

47. Noblet J, Fortune H, Shi XS, et al. (1994) Prediction of net energy value of feeds for growing pigs. J Anim Sci 72, 344-354.

48. Baum N, Carmelo C \& Carlton CE (1975) Blood urea nitrogen and serum creatinine. Physiology and interpretations. Urology 5, 583-588.

49. Kaneko JJ (1980) Clinical Biochemistry of Domestic Animals. 3rd ed. New York: Academic Press.

50. Stonard MD (1990) Assessment of renal function and damage in animal species. A review of the current approach of the academic, governmental and industrial institutions represented by the Animal Clinical Chemistry Association. J Appl Toxicol 10, 267-274. 